\title{
Effects of Recombinant Tumor Necrosis Factor on Proliferation and Differentiation of Leukemic and Normal Hemopoietic Cells In Vitro \\ Relationship to Cell Surface Receptor
}

\author{
Christina Peetre, Urban Gullberg, Eva Nilsson, and Inge Olsson \\ Division of Hematology, Department of Medicine, University of Lund, Lund, Sweden
}

\begin{abstract}
The clonogenic growth of myeloid leukemia cell lines was inhibited by recombinant tumor necrosis factor (rTNF) at 1-15 pM concentration. However, wild type (promyelocytic) HL-60 cells were highly resistant to growth inhibition, but responded with differentiation into monocyte-like cells at 100 pM rTNF. The clonogenic growth of fresh acute myeloid leukemia cells was inhibited by $50 \%$ at $\sim 15$ pM rTNF. The growth of normal granulocyte-macrophage progenitors (CFU-GM) was also inhibited (by 50 pM rTNF), as was the growth of erythroid progenitors (BFU-E) (by 150 pM rTNF). A synergistic antiproliferative effect was demonstrated between rTNF and recombinant interferon- $\gamma$. Use of radioiodinated rTNF enabled us to detect 1,5002,100 binding sites on myeloid cell lines at $4^{\circ} \mathrm{C}$ with $K_{d}$ of $\sim 300$ pM. At $37^{\circ} \mathrm{C}$, the transfer of bound ligand to lysosomes was followed by degradation, inhibited by $\mathrm{NH}_{4}{ }^{+}$. No correlation was observed between the number of binding sites or affinity at $4^{\circ} \mathrm{C}$ and antiproliferative response to the addition of rTNF.
\end{abstract}

\section{Introduction}

Biologically active polypeptides such as lymphokines and monokines may be of use in fighting leukemia because of their ability to inhibit proliferation and induce differentiation. We (1, 2 ) and others $(3,4)$ have demonstrated that T-lymphocytes can produce polypeptides called differentiation-inducing factors (DIF) ${ }^{1}$ that induce differentiation of the promyelocytic HL-60 cell line. In addition, DIF caused a primary growth inhibition of other hemopoietic cell lines (Gullberg U., E. Nilsson, M. G. Sarngadharan, and I. Olsson, submitted for publication.). Therefore we have now investigated whether the cytotoxic and cytostatic factor, tumor necrosis factor (TNF), has similar properties, and we have tried to relate the effects observed to TNF binding to the cell surface of hemopoietic cells.

Address all correspondence to Inge Olsson, M.D., Research Department
2, E-blocket, Lund Hospital, S-221 85 Lund, Sweden.
Received for publication 11 April 1986 and in revised form 7 July
1986.
1. Abbreviations used in this paper: AML, acute myeloid leukemia;
BFU-E, erythroid progenitor; CFU-GM, granulocyte-macrophage pro-
genitor; DIF, differentiation-inducing factor, FBS, fetal bovine serum;
IFN- $\gamma$, interferon- $\gamma$; NBT, nitroblue tetrazolium; rTNF, recombinant
tumor necrosis factor; SDS-PAGE, sodium dodecyl sulfate-polyacryl-
amide gel electrophoresis; TNF, tumor necrosis factor.

J. Clin. Invest.

(c) The American Society for Clinical Investigation, Inc.

$0021-9738 / 86 / 12 / 1694 / 07 \quad \$ 1.00$

Volume 78, December 1986, 1694-1700
TNF, detected in serum of mice and rabbits injected with bacillus Calmette-Guérin and endotoxin (5), is produced by macrophages (6). Also lymphotoxin, produced by some EpsteinBarr virus-transformed B cell lines after exposure to a phorbol ester, is active in the classical tumor necrosis assay (7). The promyelocytic HL-60 $(8,9)$ and the monoblastic U-937 (8) cell lines secrete TNF when stimulated with phorbol esters. TNF was purified, and synthetic oligonucleotides corresponding to a partial amino acid sequence were used for isolation and cloning of TNF cDNA (9-11). As a result, human recombinant TNF (rTNF) was produced in Escherichia coli (8-11). The gene that encodes TNF was identified in a genomic library $(11,12)$. It seems that TNF belongs to a family of polypeptides with similar biological activities. Thus the gene coding for the cytotoxic factor lymphotoxin was cloned, and the sequence comparison revealed extensive homologies (13) between TNF and lymphotoxin. A factor called cachectin, which is produced in macrophages and specifically suppresses the enzyme lipoprotein lipase in adipocytes, may be identical with TNF (14). Cachectin inhibits the activity of fat-producing (lipogenic) enzymes in cultured adipocytes (15). It may play a role in the development of cachexia in chronic inflammatory disease.

The proliferative response to TNF was reported to vary among carcinoma and sarcoma cell lines (16) and did not correlate to the number of binding sites per cell. High-affinity receptors for TNF have been demonstrated on HeLa and lymphoblastoid cells, which are sensitive to TNF-mediated growth inhibition $(17,18)$. Preincubation of cells with interferon- $\gamma$ increased the number of TNF receptors (19). Effects of TNF on normal and leukemic hemopoietic cells have not been reported. Therefore we investigated growth inhibitory and differentiation effects on myeloid leukemic cell lines, fresh leukemic progenitor cells, and normal hemopoietic progenitors. The data show varying sensitivity of these cells to the antiproliferative effects of rTNF. Some cell lines that were resistant to growth inhibition at picomolar concentration of rTNF responded with differentiation at higher concentrations. We also related these effects to cell surface binding, internalization, and degradation of endocytosed rTNF.

\section{Methods}

Cell lines. Wild type HL-60 (20), a subclone of HL-60 (HL-60-10), U937 (21), K-562, (22), and KG-1 (23) cell lines, were maintained in suspension culture in RPMI 1640 medium with $10 \%$ fetal bovine serum (FBS). The same medium was used for assays of differentiation and growth inhibition. All experiments were performed with cells in a logarithmic growth phase.

Tumor necrosis factor and interferon- $\gamma($ IFN- $\gamma)$. Recombinant human TNF (produced by Genentech, Inc., San Francisco, CA) was supplied by Boehringer Ingelheim, Vienna, Austria. The IFN- $\gamma$ produced by recombinant technology was obtained from the same company. The activity of TNF assayed on L-929 fibroblast cells in the presence of $1 \mu \mathrm{g} / \mathrm{ml}$ of 
actinomycin $\mathrm{D}(13)$ was $38 \times 10^{6} \mathrm{U} / \mathrm{mg}(646 \mathrm{U} / \mathrm{pmol})$. The IFN- $\gamma$ contained $20 \times 10^{6} \mathrm{U} / \mathrm{mg}$ of protein.

Assays for differentiation and growth inhibition. For differentiation assays, 1-ml aliquots $2 \times 10^{5} / \mathrm{ml}$ wild type HL-60 (passage 20-45) were incubated with rTNF. After $4 \mathrm{~d}$, the cell number, viability, number of nonspecific esterase-positive cells with $\alpha$-naphthyl butyrate as substrate (24), and number of cells with a capacity to reduce nitroblue tetrazolium (NBT) were determined (2).

The growth-inhibitory effect of TNF on cell lines was determined by use of agar culture. In the latter, 2,000 cells were seeded in $1 \mathrm{ml}$ of $0.3 \%$ agar on top of $1 \mathrm{ml}$ of $0.5 \%$ agar in $35-\mathrm{mm}$ tissue culture dishes. Colonies were counted after $10 \mathrm{~d}$.

Assay for granulocyte-macrophage progenitors (CFU-GM). Human marrow cells $\left(10^{5}\right)$ with $d<1.077 \mathrm{~g} / \mathrm{ml}$, obtained by centrifugation in Ficoll-Hypaque was grown in $1 \mathrm{ml}$ of $0.3 \%$ agar on top of $1 \mathrm{ml}$ of $0.5 \%$ agar in growth medium with 15\% FBS in 35-mm tissue culture dishes. As a source of colony stimulating activity, human placenta-conditioned medium was used after partial purification by chromatography on Sephadex G-75 (Pharmacia Co., Sweden). The plates were scored after 7, 10 , and $14 \mathrm{~d}$. The effects of TNF on colonies counted on day 10 are documented in Fig. 1.

Assay for clonal growth of acute myeloid leukemia (AML) cells. Bone marrow cells from 10 patients with untreated AML were cultured in

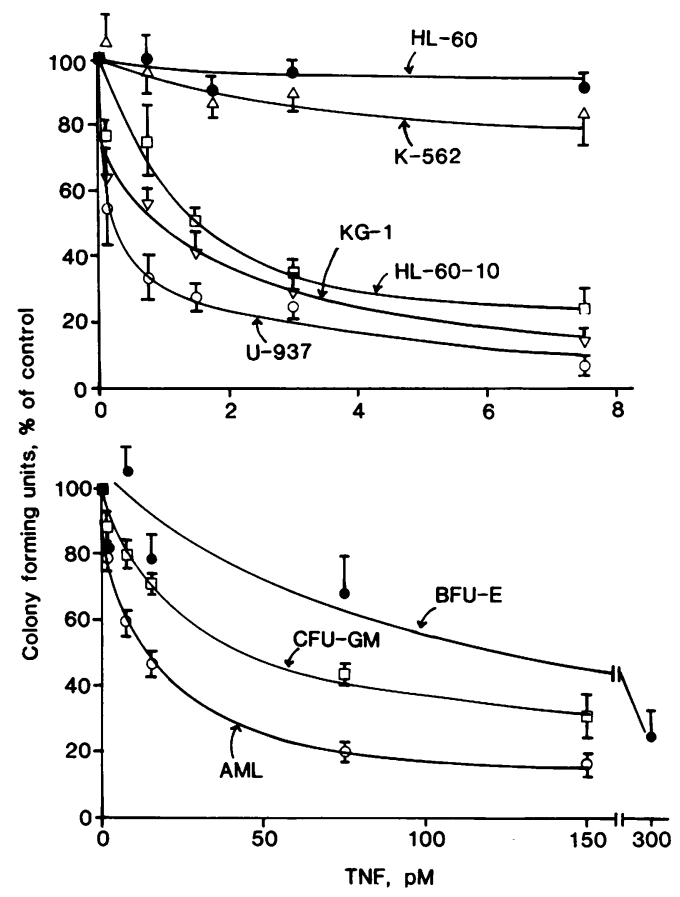

Figure 1. Proliferation-inhibitory effects on clonal growth in agar of myeloid cell lines HL-60 (๑), K-562 ( $\triangle)$, KG-1 ( $\nabla)$, HL-60-10 ( $\square)$, and U-937) (O). Experiments were performed four to six times on each cell line; bars indicate SEM. Also included are data on proliferation-inhibitory effects on normal hemopoietic stem cells, BFU-E $(n=5)(\bullet)$, and CFU-GM $(n=5)(\square)$, as well as on fresh AML cells $(n=10)(0)$; bars indicate SEM. For assays of effects on cell lines (top) the following TNF concentrations were used: $0.15,0.75,1.5,3.0$, and $7.5 \mathrm{pM}$. For assays of the effects on hemopoietic progenitors and AML cells (bottom) the following concentrations were used: $1.5,7.5,15,75$, and 150 $\mathrm{pM}$, except for assays of the effect on BFU-E, where the highest concentration was $300 \mathrm{pM}$. Colony-forming units are given as percent of control after $10 \mathrm{~d}$ of culture for the cell lines, after $20 \mathrm{~d}$ for BFU-E, after $10 \mathrm{~d}$ for CFU-GM, and after $7 \mathrm{~d}$ for AML cells. The plating efficiency was $30 \%$ for wild type HL-60, $40 \%$ for K-562, $15 \%$ for KG-1, $30-50 \%$ for HL-60-10, and 40-50\% for U-937. Control incubations without TNF contained 86 \pm 50 (SD) BFU-E, 140 \pm 56 (SD) CFU-GM, and $487 \pm 284(\mathrm{SD})$ clonogenic AML cells. agar as described above for CFU-GM. Cell aggregates containing more than three cells were scored at day 7 and taken to represent clonogenic cells. According to the Fab classification (25), there were 5 M2 patients, $1 \mathrm{M} 3$ patient, $3 \mathrm{M} 4$ patients, and $1 \mathrm{M} 5$ patient.

Assay for erythroid progenitors (BFU-E). Mononuclear blood cells from healthy individuals were separated from heparinized blood by centrifugation on Ficoll-Hypaque. Cells, $2 \times 10^{5}$ in $1-\mathrm{ml}$ vol in $35-\mathrm{mm}$ petri dishes, were grown in $0.8 \%$ methyl cellulose in Iscove's modification of Dulbecco's medium with glutamine and Hepes. The following additions were made: $30 \%$ FBS, $10 \%$ conditioned medium from the Mo-cell line (kindly provided by Dr. David Golde, Department of Oncology-Hematology, University of California, Los Angeles, CA), $20 \mathrm{mM}$ glutamine, $50 \mu \mathrm{M} \beta$-mercaptoethanol, $1 \mathrm{U} / \mathrm{ml}$ of human urinary erythropoietin (kindly provided by Dr. Miloslav Beran, M. D. Anderson Hospital, Houston, TX), 1.7\% (wt/vol) bovine serum albumin (BSA), $1.6 \mu \mathrm{M} \mathrm{FeCl}_{3}$, and $4.5 \mu \mathrm{M}$ transferrin saturated with $\mathrm{FeCl}_{3}$. The plates were incubated for $20 \mathrm{~d}$ at $5 \% \mathrm{PCO}_{2}$ in a fully humidified incubator. Erythropoietic bursts consisting of several individual colonies were counted as described (26) after $20 \mathrm{~d}$. The single compact colony type composed a minority of the erythroid growth from peripheral blood mononuclear cells. These were also counted as BFU-E as described (26). Both types of BFU-E consisted of more than 500 cells. Control incubations without TNF contained $86 \pm 49.7$ (SD) BFU-E/dish.

Iodination of TNF. Iodination was performed using the two-phase method described by Tejedor and Ballasta (27). Borate buffer $(50 \mu l, 50$ $\mathrm{mM}, \mathrm{pH} 8.4), \mathrm{KI}(10 \mu \mathrm{l}, 0.125 \mathrm{mM}$ in borate buffer) and $1 \mathrm{mCi}$ of carrier-free ${ }^{125}$ I (Amersham International, Amersham, Buckinghamshire, England) were mixed with $2 \mu \mathrm{g}$ rTNF containing $0.05 \%$ Tween 20 . Iodination was performed as described (27). A Sephadex G-25 column was used for isolation of the ${ }^{125}$ I-rTNF. ${ }^{125}$ I was incorporated into rTNF without loss of biological activity, as judged by its ability to inhibit the clonogenic growth of HL-60-10. The specific activity of ${ }^{125}$ I-rTNF was determined by self displacement analysis (28). For this analysis, it is assumed that the binding characteristics of labeled and unlabeled rTNF are the same.

The iodinated rTNF was subjected to sodium dodecyl sulfate-polyacrylamide gel electrophoresis (SDS-PAGE) as described previously (2). After electrophoresis gels were dried on filter paper, they were exposed to x-ray film (X-Omat S, Eastman Kodak Co., Rochester, NY) for $12 \mathrm{~h}$.

Binding of ${ }^{125}$ I-rTNF to cells. Washed cells were incubated with radioiodinated rTNF in binding buffer (RPMI, 2\% heat-inactivated FBS, and $1 \% \mathrm{BSA}$ ) in a total volume of $200 \mu \mathrm{l}$ in $1.5-\mathrm{ml}$ Eppendorf centrifuge tubes. After incubation by rotation, cells were centrifugated for $10 \mathrm{~s}$ at $8,000 \mathrm{~g}$, and the pellet was resuspended and washed twice in ice-cold binding buffer to separate free and membrane-bound ${ }^{125} \mathrm{I}$-rTNF. The radioactivity of the cell pellet was measured in a $\gamma$-counter. Specific binding was defined as the difference between total binding and the binding that occurred in the presence of a 20-fold excess of unlabeled rTNF (nonspecific binding). In the range of $2 \times 10^{6}-20 \times 10^{6}$ cells, the assay was proportional to the number of cells added. In standard assays, 5 $\times 10^{6}$ cells were used per incubation.

The occurrence of degradation products of ${ }^{125} \mathrm{I}-\mathrm{rTNF}$ in the incubation medium upon binding and internalization of ${ }^{125} \mathrm{I}-\mathrm{rTNF}$ was also determined. The incubation medium was precipitated with $10 \%$ trichloroacetic acid. The radioactivity of the supernatant was determined and taken as a measure of degraded ${ }^{125}$ I-rTNF.

Subcellular fractionation. Before homogenization of labeled cells, 5 $\times 10^{7}$ unlabeled carrier cells were added. Homogenization was at a concentration of $10^{8}$ cells $/ \mathrm{ml}$ in $0.34 \mathrm{M}$ sucrose $/ 5 \mathrm{mM}$ Hepes (pH 7.3)/0.5 mM EDTA (homogenization medium) with 40 strokes of a Dounce glass homogenizer (Kontes Glass Co., Vineland, NJ). The homogenate was diluted with the same solution and unbroken cells and nuclei were recovered by centrifugation at $700 \mathrm{~g}$ for $10 \mathrm{~min}$. For density gradient separations, $6 \mathrm{ml}$ of $12 \%$ Percoll (density $1.069 \mathrm{~g} / \mathrm{ml}$ ), in Hepes/sucrose adjusted to give a final concentration of $15-\mathrm{mM}$ Hepes, $\mathrm{pH} 7.4$, and $0.25 \mathrm{M}$ sucrose, was layered on top of a $1-\mathrm{ml}$ cushion of saturated sucrose. A 2.0-ml aliquot of the $700 \mathrm{~g}$ supernatant of the cell homogenate was 
layered on top of the Percoll. Centrifugation was performed at $32,000 \mathrm{~g}$ for $60 \mathrm{~min}$ at $4^{\circ} \mathrm{C}$ in a Sorvall RC-5B centrifuge using the SE-12 rotor (E.I. Du Pont de Nemours \& Co., Inc., Newtown, CT). Fractions were collected with a peristaltic pump. The gradient was collected in 19 fractions, and the cytosol was collected in fraction 20. Galactosyl transferase (marker for Golgi elements) (29) and $\beta$-hexosaminidase (marker for lysosomes) (30) were determined as described. The distribution of plasma membranes was determined by labeling the cell surface at $0^{\circ} \mathrm{C}$ with ${ }^{125} \mathrm{I}-$ wheat germ lectin (31) before homogenization and assaying for ${ }^{125}$ I activity of the fractions obtained from the gradient.

\section{Results}

Differentiation induction of $H L-60$. After addition of rTNF to wild type HL-60 cells, there was an increase in cells that reduced NBT when stimulated with phorbol ester (Fig. 2). There was an increase in $\alpha$-NBE-positive cells too, indicating maturation along the monocyte-macrophage pathway, which was supported also by alterations in cell morphology with the appearance of irregular nuclei and disappearance of cytoplasmic granulation. These changes occurred at 2-4 d of incubation at 100-600 pM concentration of rTNF. The maturation changes took place without inhibition of growth during the first $4 \mathrm{~d}$ of incubation (data not shown).

Proliferation inhibition of myeloid cell lines. One subclone of HL-60 (HL-60-10) was highly susceptible to the antiproliferative effect of rTNF in a clonal assay (agar culture). 1 pM rTNF inhibited growth $50 \%$ (Fig. 1). TNF did not induce visible differentiation of HL-60-10 cells; judging from the fact that no NBT-positive cells were formed. In separate experiments (data not shown), we investigated if the growth inhibitory effect on HL-60-10 was reversible or not in suspension culture. We found that if rTNF was removed from the cells by washing within 24 $h$ of addition, the effect was partly reversible. In contrast to wild type HL-60, subclones, e.g., HL-60-10, sensitive to TNF-induced growth inhibition, were $\alpha$-NBE-positive. In this respect the subclones are similar to the monoblast-like U-937 cell line, which was also highly susceptible to rTNF-induced growth inhibition, with $50 \%$ inhibition at a concentration of rTNF below $1 \mathrm{pM}$ (Fig. 1). The myeloblast-like KG-1 cell line was also highly susceptible to rTNF, while the proerythroid K-562 line was less susceptible.

Proliferation inhibition of normal hemopoietic cells and fresh AML cells. Fig. 1 shows that normal CFU-GM responded with growth inhibition to the addition of rTNF with $50 \%$ inhibition at $50 \mathrm{pM}$ rTNF. BFU-E were less susceptible than CFU-GM. Clonogenic cells (all aggregates with more than three cells

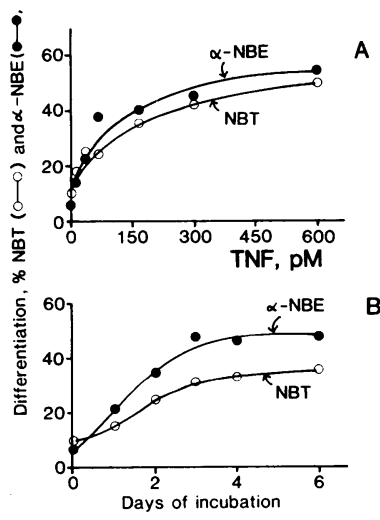

Figure 2. Differentiation induction of wild type HL-60 with rTNF. $(A)$ Cells were incubated with different concentrations of TNF for $4 \mathrm{~d}$ and the \% NBT-positive (o) and $\alpha$ NBE-positive $(\bullet)$ cells are shown. $(B)$ Cells were also incubated for different time periods with $600 \mathrm{pM}$ rTNF before analyzing NBT- and $\alpha$-NBE-positive cells. In these experiments rTNF produced no growth inhibition of HL-60 and the number of cells at $4 \mathrm{~d}$ was similar in incubations with rTNF and control incubations without $r$ TNF. counted on day 7) from 10 patients with AML responded to rTNF with $50 \%$ reduction of clonogenic growth in agar at $\sim 15$ pM rTNF. Similar results were obtained in AML by scoring small clusters (3-20 cells), large clusters (20-40 cells), or colonies at 7,10 , or $14 \mathrm{~d}$ of culture (data not shown).

Synergistic antiproliferative effect of $r T N F$ and $r I F N-\gamma$. The combined effect of rTNF and rIFN- $\gamma$ on the clonogenic growth of HL-60-10 was investigated (Fig. 3). rIFN- $\gamma, 100-500 \mathrm{U} / \mathrm{ml}$, did not significantly inhibit growth. However, additions of 100 $500 \mathrm{U} / \mathrm{ml}$ of rIFN- $\gamma$ clearly potentiated the antiproliferative effect of rTNF, thus indicating a synergistic action between rTNF and rIFN- $\gamma$. This result is consistent with results from a previous report on synergism between rTNF and rIFN- $\gamma$ for proliferation inhibition on human carcinoma cell lines (16).

Binding of ${ }^{125}$ I-rTNF to hemopoietic cells. TNF was iodinated with a two-phase labeling system (27). When iodinated rTNF was subjected to SDS-PAGE, a major $M_{\mathrm{r}} 17,000$ component was visible on the fluorogram (Fig. 4). The specific activity was determined by self-displacement analysis (Fig. 4) of HL-60-10 cells. This method gives an estimate of the specific radioactivity of the TNF molecules that actually bind to the target cells in the assay. The parallel displacement curves for the total rTNF and unlabeled rTNF (Fig. 4) indicated that the binding affinity of iodinated and native TNF molecules was similar. This was obvious also from titration experiments where the growth-inhibitory effects of iodinated rTNF and unlabeled rTNF were compared (data not shown). The self-displacement analysis gave an estimate of the specific activity of $2.1 \times 10^{6} \mathrm{cpm} / \mathrm{pmol}$.

The competition for ${ }^{125} \mathrm{I}$-rTNF binding to hemopoietic cell lines by unlabeled rTNF is shown in Fig. 5 . All cell lines tested, HL-60, HL-60-10, KG-1, and K-562, showed binding, competed for by unlabeled rTNF. HL-60 cells induced to differentiate into granulocyte-like cells with retinoic acid (32) and into monocytelike cells with $1 \alpha, 25$ dihydroxycholecaliferol (33) retained binding sites for rTNF (data not shown).

Binding, internalization, and degradation of ${ }^{125} I-r T N F$. The binding of ${ }^{125} \mathrm{I}-\mathrm{rTNF}$ to HL-60-10 cells was measured at both $4^{\circ}, 23^{\circ}, 37^{\circ} \mathrm{C}$. Maximum binding was observed after $2 \mathrm{~h}$ at $4^{\circ} \mathrm{C}$, and after $10 \mathrm{~min}$ at $37^{\circ} \mathrm{C}$ (Fig. 6). Maximum binding was observed after $20 \mathrm{~min}$ at $23^{\circ} \mathrm{C}$ (data not shown). Incubation at $37^{\circ} \mathrm{C}$ resulted in a decrease with time of cell-associated rTNF, possibly indicating degradation of ${ }^{125} \mathrm{I}-\mathrm{rTNF}$. Actually the decrease in cell-associated ${ }^{125} \mathrm{I}-\mathrm{rTNF}$ after $\sim 2 \mathrm{~h}$ was accompanied by the release of a corresponding amount of acid-soluble material into the medium (Fig. 6), indicating degradation at $37^{\circ} \mathrm{C}$ but not at $4^{\circ} \mathrm{C}$. When binding experiments at $37^{\circ} \mathrm{C}$ were performed in the presence of $10 \mathrm{mM} \mathrm{NH}_{4} \mathrm{Cl}$, no decrease with time was seen for cell-associated rTNF. Furthermore the occurrence of acid-soluble material in the medium was considerably decreased, indicating that $\mathrm{NH}_{4}^{+}$protected against degradation of rTNF.

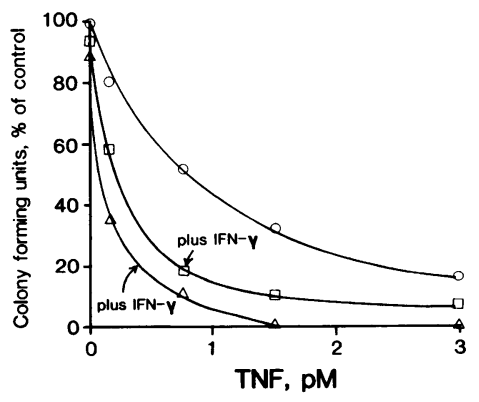

Figure 3. Synergistic growth-inhibitory effects between rTNF and rIFN- $\gamma$. HL-60-10 cells were cultured in agar at different concentrations of rTNF for $10 \mathrm{~d}$ without $(\mathrm{O})$ and with $100 \mathrm{U} / \mathrm{ml}(\square)$, or with 500 $\mathrm{U} / \mathrm{ml}(\Delta)$ of rlFN- $\gamma$. Results are given as colony-forming units, percent of control. 


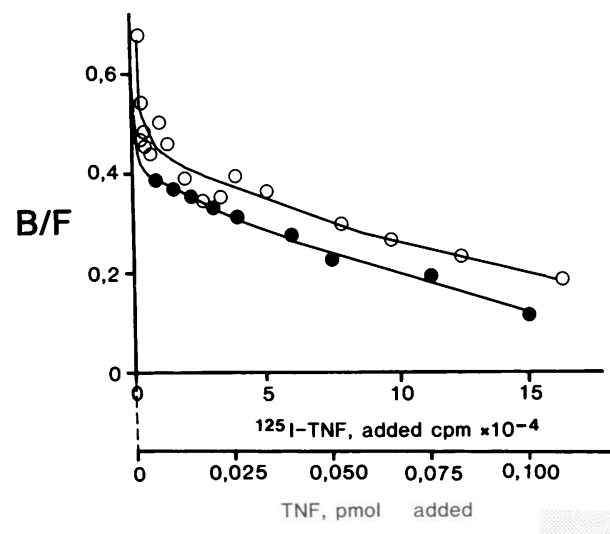

A

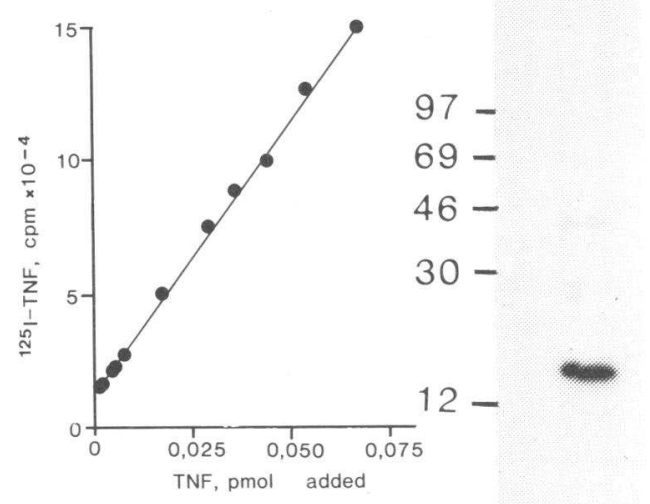

Figure 4. Determination of specific activity of ${ }^{125}$ I-labeled rTNF by self-displacement analysis. $(A) \mathrm{B} / \mathrm{F}$ ratios are plotted against total radioactivity added $(O)$ and against amount of unlabeled rTNF added $(\bullet)$. (B) The total radioactivity added is plotted against amount of unlabeled rTNF (๑). These data are obtained from the portions of $A$ in which $\mathrm{B} / \mathrm{F}$ ratios are the same for both curves. Specific activity corresponding to $2.1 \times 10^{6} \mathrm{cpm} / \mathrm{pmol}$ is determined from the slope of the line. In $B$, electrophoretic analysis of ${ }^{125}$ I-rTNF by SDS-PAGE is also shown, with position of molecular weight markers indicated to the left. The picture of the gel is reduced to $38 \%$ of the original gel.

The finding of a temperature-dependent degradation of cellassociated ${ }^{125}$ I-rTNF suggested that rTNF may be degraded after receptor-mediated endocytosis and fusion of receptosomes with lysosomes. Using a Percoll density gradient system, we attempted to determine if bound rTNF resided either within a vesicular

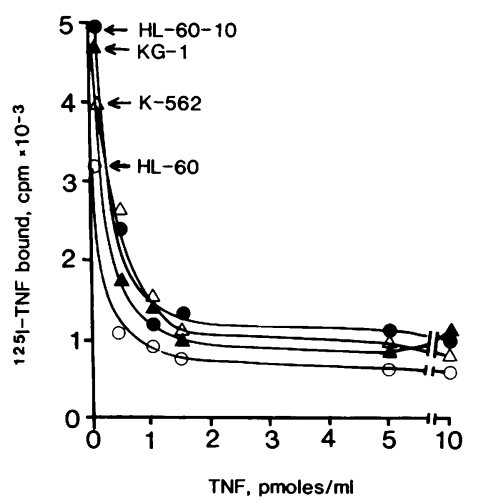

Figure 5. Binding of ${ }^{125} \mathrm{I}$ rTNF to myeloid cell lines HL-60 (0), HL-60-10 (๑), KG-1 ( $\triangle)$, and K-562 ( $\triangle$ ). The competition for ${ }^{125}$ I-labeled rTNF binding by various concentrations of unlabeled rTNF added was investigated. These binding experiments were performed at room temperature for $60 \mathrm{~min}$, and the results are expressed as cpm ${ }^{125}$ I-rTNF bound to the cells and is plotted against the concentration of unlabeled rTNF added.

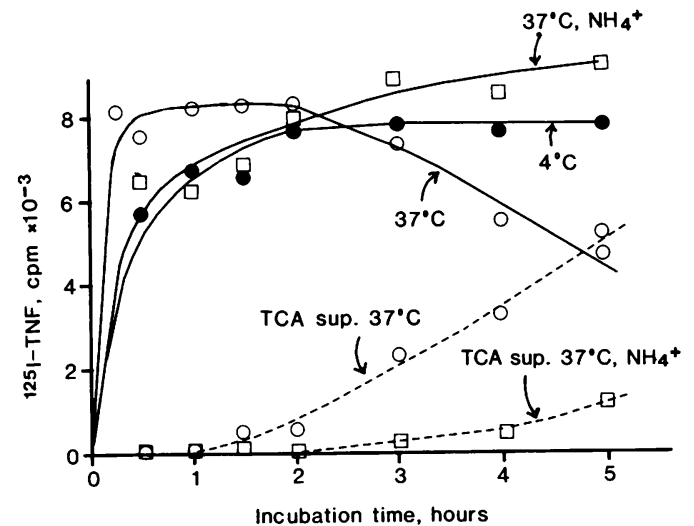

Figure $6 .{ }^{125} \mathrm{I}-\mathrm{rTNF}$ binding to $\mathrm{HL}-60-10$ cells at $4{ }^{\circ} \mathrm{C}(\bullet)$ and at $37^{\circ} \mathrm{C}$ (O) as a function of time of incubation. Incubations were also performed in the presence of $10 \mathrm{mM} \mathrm{NH}_{4}{ }^{+}(\square)$. All values are corrected for nonspecific binding obtained at a 20 -fold excess of unlabeled rTNF. The occurrence of degradation products of ${ }^{125} \mathrm{I}-\mathrm{rTNF}$ in the incubation medium was determined by precipitation with $10 \%$ trichloroacetic acid (TCA) in ice and measuring the radioactivity of the supernatant. Data are given for TCA supernatants obtained from binding at $37^{\circ} \mathrm{C}$ in the absence (O) and presence ( $\square$ ) of $10 \mathrm{mM} \mathrm{NH}_{4}{ }^{+}$. These data are corrected for radioactivity of TCA supernatants obtained from binding studies at $4^{\circ} \mathrm{C}$. The latter showed no increase in radioactivity of TCA supernatants with time, thus indicating that no degradation occurred at $4^{\circ} \mathrm{C}$.

compartment in the cell or remained bound to membrane. The gradient system allowed separation of lysosomes from Golgi and plasma membrane fractions. The positions of these fractions were determined by marker enzymes (Fig. $7 \mathrm{~A}$ ). Cells were loaded with ${ }^{125} \mathrm{I}$-rTNF at $4^{\circ}$ or $37^{\circ} \mathrm{C}$. After loading at $4^{\circ} \mathrm{C}$ for $60 \mathrm{~min}$, cells were homogenized at $0^{\circ} \mathrm{C}$ and added to Percoll for gradient centrifugation at $4^{\circ} \mathrm{C}$. The ${ }^{125} \mathrm{I}-\mathrm{rTNF}$ was present in a fraction that corresponded exactly with the localization of plasma membranes (Fig. $7 \mathrm{~B}$ ). No delivery to denser organelles was seen. However, loading for $30 \mathrm{~min}$ at $37^{\circ} \mathrm{C}$ resulted in the occurrence of labeled material in the most dense fractions corresponding to the distribution of lysosomes and a clear decrease of plasma membrane-associated ${ }^{125}$ I-rTNF. Increased loading times resulted in an increase in radioactivity in the most dense fractions and a decrease in the light fractions. These data demonstrate that ${ }^{125}$ I-rTNF is internalized, and it is also degraded at least in part, according to data of Fig. 6 .

We attempted to obtain more detailed information on internalization and degradation of ${ }^{125} \mathrm{I}$-rTNF by modulating these processes by several means (Fig. $7 \mathrm{C}$ ). Internalization was not blocked by $10 \mu \mathrm{M}$ colchicine, which disrupts microtubules. Moreover $10 \mu \mathrm{g} / \mathrm{ml}$ cytochalasin B, which disrupts microfilaments, did not block internalization either (data not shown). Thus internalization does not require an intact cytoskeleton. Monensin, a monocarboxylic proton ionophore that exchanges $\mathrm{Na}^{+}$ions for protons and raises the normally acidic $\mathrm{pH}$ of endocytic vacuoles (34), did not interfere with internalization (Fig. $7 \mathrm{C}$ ). $10 \mathrm{mM} \mathrm{NH}_{4} \mathrm{Cl}$ did not block internalization either (Fig. $7 \mathrm{C}$ ). In contrast to $\mathrm{NH}_{4}{ }^{+}$, incubation with monensin and chloroquine did not inhibit the degradative pathway resulting in the intracellular accumulation of intact ligand without release of acid-soluble degradation products to the medium (data not shown). 

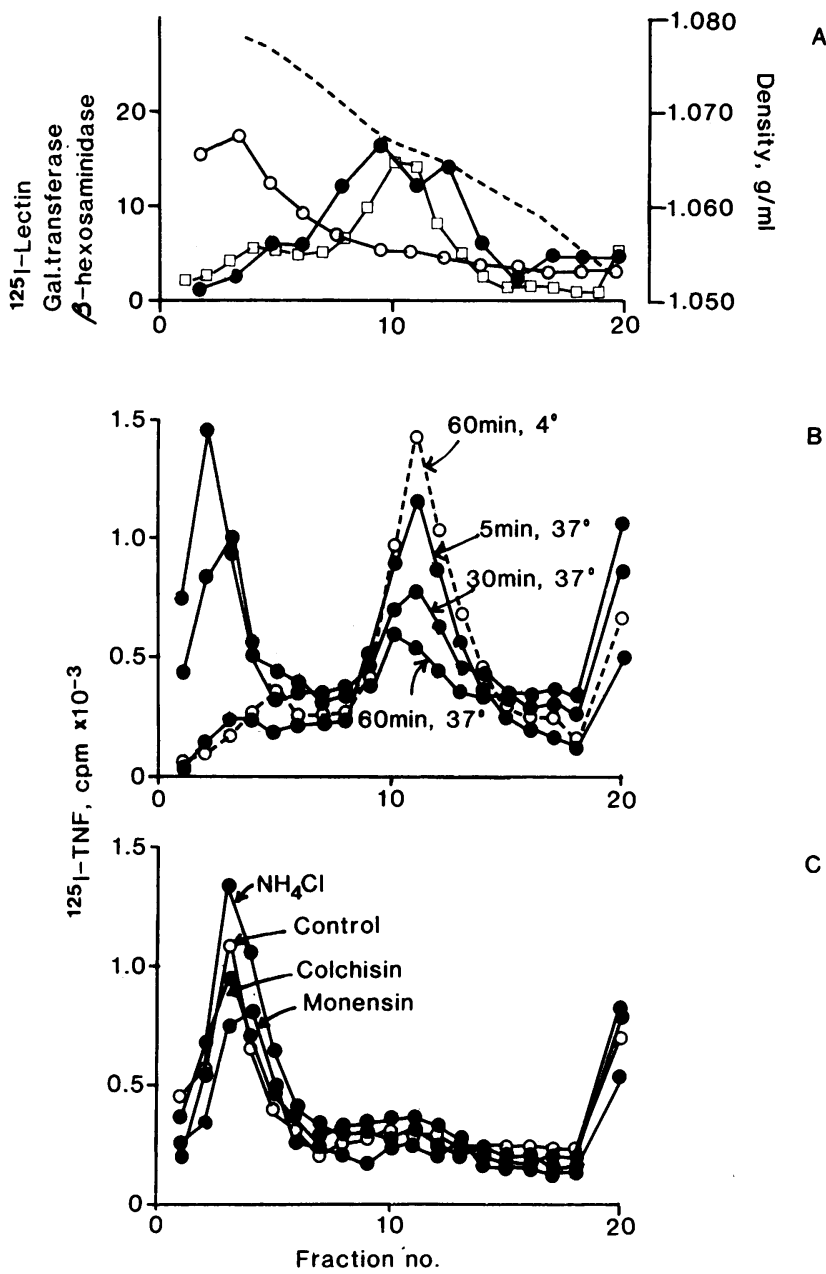

B

C

Figure 7. Demonstration of internalization of bound ${ }^{125}$ I-rTNF in HL60-10 cells by use of centrifugation of cell homogenates in a Percoll density gradient. Fraction No. 20 represents the cytosol. $(A)$ The distribution in the gradient of ${ }^{125} \mathrm{I}$-lectin, as a marker for plasma membrane ( $\square$ ); galactosyl transferase, as a marker for Golgi elements (๑); and $\beta$-hexosaminidase as a marker for lysosomes ( 0 ), is shown, as well as the density of fractions (-...-). (B) Distribution in the gradient of ${ }^{125} \mathrm{I}$-rTNF of homogenates prepared after incubation of intact cells with ${ }^{125} \mathrm{I}-\mathrm{rTNF}$ for 5,30 , and $60 \mathrm{~min}$ at $37^{\circ} \mathrm{C}(\bullet)$ or $60 \mathrm{~min}$ at $4^{\circ} \mathrm{C}$ (o). (C) Distribution in the gradient of ${ }^{125} \mathrm{I}-\mathrm{rTNF}$ of homogenates prepared after incubation of intact cells with ${ }^{125} \mathrm{I}-\mathrm{TNF}$ for $60 \mathrm{~min}$ at $37^{\circ} \mathrm{C}$ in the presence of $10 \mathrm{mM} \mathrm{NH}_{4} \mathrm{Cl}, 10 \mu \mathrm{M}$ colchisin, $1 \mu \mathrm{M}$ monensin (๑), or no addition (o) (control).

We also demonstrated (data not shown) that the cells internalized ${ }^{125} \mathrm{I}-\mathrm{rTNF}$ at $20^{\circ} \mathrm{C}$, but without degradation. Results of Percoll separations of homogenates from cells loaded at $20^{\circ} \mathrm{C}$ showed that labeled material accumulated in organelles with a density intermediate between plasma membranes and lysosomes. Thus endocytosis continued at $20^{\circ} \mathrm{C}$, but fusion of receptosomes with lysosomes might not have occurred, because degradation did not occur.

Equilibrium binding constants, receptor numbers, and cellular response. The kinetics for binding of ${ }^{125} \mathrm{I}-\mathrm{rTNF}$ to various myeloid cell lines was subjected to Scatchard analysis (35). Dissociation constants and maximum number of binding sites were calculated from the best fit equations. The binding of ${ }^{125} \mathrm{I}-\mathrm{rTNF}$ to cell lines HL-60, HL-60-10, K-562, KG-1, and U-937 was homogeneous at $4^{\circ} \mathrm{C}$, with a single dissociation constant $\left(K_{d}\right)$ of $\sim 300$ pM with $1,500-2,100$ binding sites per cell. Table I summarizes data for HL-60 and HL-60-10 at various temperatures. Wild type HL-60 showed homogeneous binding at $4^{\circ}$, $23^{\circ}$, and $37^{\circ} \mathrm{C}$, whereas HL-60-10 showed bimodal binding at higher temperatures. Thus a small number of "very high" affinity $\left(K_{\mathrm{d}}=5-15 \mathrm{pM}\right)$ binding sites (20-40 per cell) was observed on HL-60-10 at elevated temperatures. Similar very high affinity binding was also seen on K-562, U-937, and KG-1 at elevated temperature (data not shown). This very high affinity binding observed at elevated temperature may be an expression of a temperature-dependent receptor or the result of ligand internalization. Investigations on isolated membranes are needed to clarify this point further.

Thus the number of high affinity sites was similar in various cell lines at $4^{\circ} \mathrm{C}$, and the binding sites had a similar affinity for the ligand in various cell lines, whereas the growth-inhibitory effect of TNF varied considerably (Fig. 1). Obviously the antiproliferative effect on the cell lines was not reflected in variations of the number of binding sites or affinity of the receptor at $4^{\circ} \mathrm{C}$. However, the "very high" affinity binding demonstrated at elevated temperature was not observed in wild type HL-60 cells, which were highly insensitive to the antiproliferative effect.

Percoll density gradient centrifugation of cell homogenates revealed that internalization of bound ligand occurred equally well in wild type HL-60 and HL-60-10 (data not shown). Thus differences in internalization rates do not explain the different cellular response in wild type HL-60 and HL-60-10.

\section{Discussion}

This work has demonstrated that rTNF has a profound antiproliferative effect on some myeloid leukemia cell lines with $50 \%$ inhibition of clonal growth at $\sim 1 \mathrm{pM}$ concentration of rTNF. However, the susceptibility to rTNF varied among different clones of HL-60. Some of these were highly susceptible to growth inhibition, but wild type HL-60 was resistant. Actually wild type HL-60 was induced to differentiate into monocytelike cells at high concentrations (100-600 pM) of rTNF. Thus rTNF displays different actions on clones from the same cell line, and target cells resistant to the antiproliferative effect at low concentrations may respond with differentiation at higher concentrations of rTNF. The final result in both cases is inhibition of the self renewal capacity of clonogenic cells. Similar effects have been demonstrated for a T-lymphocyte-derived DIF $(1,2)$. However DIF and TNF are distinctive polypeptides as they have different biochemical characteristics (2). Moreover, a neutralizing anti-TNF rabbit antiserum did not neutralize the DIF effect (unpublished data), but both DIF and TNF may belong to a family of polypeptides with similar biological activities.

The fraction of cells with clonal self renewal is high in immortalized cell lines but low among fresh leukemia cells from patients with acute myeloid leukemia. For natural reasons the patients investigated were selected because their marrow cells had a relatively high plating efficiency, which correlated with a less favorable prognosis (36). Therefore we were convinced that in such cases the majority of the clonogenic cells that grow in agar are leukemic and not normal cells, and that the results reflect the effect of rTNF on leukemic cells.

The antiproliferative effect of rTNF was not specific for leukemic cells. Also normal hemopoietic progenitors were susceptible, though less so than leukemic cells. Recent data demonstrated that the molecules responsible for the cytotoxic or 
Table I. Dissociation Constants and Receptor Numbers of ${ }^{125}$ I-rTNF Binding to $H L-60$ and $H L-60-10$ Cells and Growth Inhibition by rTNF

\begin{tabular}{|c|c|c|c|c|c|c|}
\hline \multirow[b]{2}{*}{ Cell } & \multirow[b]{2}{*}{$\begin{array}{l}\text { Incubation } \\
\text { temperature }\end{array}$} & \multicolumn{2}{|l|}{ High affinity receptor } & \multicolumn{2}{|c|}{ "Very high" affinity receptor } & \multirow[b]{2}{*}{$\begin{array}{l}50 \% \text { growtl } \\
\text { inhibition }\end{array}$} \\
\hline & & $\begin{array}{l}\text { Number of receptors } \\
\text { per cell }\end{array}$ & $\begin{array}{l}\text { Dissociation } \\
\text { constant }\end{array}$ & $\begin{array}{l}\text { Number of receptors } \\
\text { per cell }\end{array}$ & $\begin{array}{l}\text { Dissociation } \\
\text { constant }\end{array}$ & \\
\hline & & & $p M$ & & $p M$ & $p M$ \\
\hline \multirow[t]{3}{*}{ HL-60 } & $4^{\circ} \mathrm{C}$ & 1,400 & 350 & 0 & - & - \\
\hline & $23^{\circ} \mathrm{C}$ & 1,500 & 170 & 0 & - & - \\
\hline & $37^{\circ} \mathrm{C}$ & 6,300 & 170 & 0 & - & 750 \\
\hline \multirow[t]{3}{*}{ HL-60-10 } & $4^{\circ} \mathrm{C}$ & 2,100 & 310 & 0 & - & - \\
\hline & $23^{\circ} \mathrm{C}$ & $2,800-3,500$ & 270 & $0-20$ & 1.2 & - \\
\hline & $37^{\circ} \mathrm{C}$ & $1,200-2,200$ & $330-600$ & $19-43$ & $5-15$ & 1 \\
\hline
\end{tabular}

Binding studies were performed as described in Methods. Incubations were for $2 \mathrm{~h} \mathrm{at} 4^{\circ} \mathrm{C}, 1 \mathrm{~h}$ at $23^{\circ} \mathrm{C}$, and 20 min at $37^{\circ} \mathrm{C}$ to reach steady state. The cells were incubated at 22 different concentrations $(5-800 \mathrm{nM})$ of ${ }^{125} \mathrm{I}-\mathrm{rTNF}$ in the absence or presence of excess unlabeled rTNF to correct for unspecific binding. When more than one experiment was performed, the range of data obtained is given.

cytostatic effect of supernatant from natural killer cells on CFUGM are antigenically, functionally, and biochemically similar to or identical with TNF produced by monocytes (37). Our data showed that CFU-GM were more sensitive to rTNF than BFUE. This is consistent with data of a recent abstract on the effect of TNF on human bone marrow hemopoietic progenitor cells (38). However, some human cancer cell lines (16-18) and some of the myeloid leukemia cell lines of this report were extremely sensitive to TNF. The mechanism for this potent and selective effect is unknown. A synergistic cytotoxic interaction between TNF and IFN- $\gamma$ reported for human cancer cell lines (7) and hematopoietic progenitors $(37,38)$ was shown for the myeloid cell lines too.

The present data also show binding of rTNF to myeloid cells. Receptor expression was not influenced by cellular differentiation, as uninduced and induced HL-60 cells both demonstrated saturable binding of TNF. Binding of radioiodinated recombinant TNF to myeloid cell lines such as HL-60-10 and U937 at $4^{\circ} \mathrm{C}$ was saturable, reversible, and of high affinity $\left(K_{d}\right.$ $=300 \mathrm{pM}$ ). The surface-bound ligand was internalized at elevated temperature. Intracellular rTNF was degraded into trichloroacetic acid-soluble material. When binding studies were performed at elevated temperature, the Scatchard plot of the binding data was biphasic. In addition to binding sites detectable at $4^{\circ} \mathrm{C}$, the presence of a small number of very high affinity binding sites was suggested. However, this result could also be a consequence of ligand internalization that took place at elevated temperature but not at $4^{\circ} \mathrm{C}$. It remains to be determined if purified plasma membranes have two classes of binding sites or not. A similar result was reported for rINF- $\gamma$, but isolated plasma membranes bound ligand in a unimodal manner at either $4^{\circ}$ or $37^{\circ} \mathrm{C}$, indicating that only one class of high-affinity receptor was present for IFN- $\gamma(39)$.

Our data demonstrate that low temperature preferentially inhibited rTNF degradation while endocytic uptake continued at $20^{\circ} \mathrm{C}$. The results from subcellular fractionation indicated that at $20^{\circ} \mathrm{C}$, unlike at $37^{\circ} \mathrm{C}$, internalized rTNF did not reach the lysosomes but remained in receptosomes. This agrees with data for the asialoglycoprotein receptor system for which endocytosis also continued at $20^{\circ} \mathrm{C}$ while lysosomal degradation was completely inhibited $(40,41)$. On the other hand endocytic uptake of insulin in adipocytes is more temperature-sensitive than intracellular processing and release of internalized insulin (42). Thus differences may exist in mechanisms of uptake and degradation of various ligand receptor systems.
Internalization of rTNF was independent of an intact cytoskeleton, as agents that disrupt microfilaments or microtubules did not inhibit the internalization. Transport of ligand to lysosomes seemed to be independent of acidification of endocytic vacuoles, as transport was not blocked by $\mathrm{NH}_{4}{ }^{+}$or monensin. The latter agent, which exchanges $\mathrm{Na}^{+}$ions for protons, disrupts an ion gradient necessary for the budding of vesicles from the Golgi apparatus and also blocks the movement of newly synthesized plasma membrane proteins from the Golgi to the plasma membrane (34). Monensin can also block receptor recycling (43).

TNF receptors have now been found in human and murine carcinoma cell lines $(16,18,19)$, some lymphoblastoid cell lines (17), and myeloid cells of the present study. Comparable numbers of receptors $(2,000-6,000)$ with similar binding affinities at $4^{\circ} \mathrm{C}$ $\left(K_{d}=200-300 \mathrm{pM}\right)$ were present on carcinoma lines and myeloid leukemia lines. However, we cannot definitely conclude that a single type of TNF receptor is present on different cells. The presence of TNF receptors was not found to be correlated with TNF sensitivity (18) and thus did not provide a predictive test for the antiproliferative response to TNF. As to various myeloid cell lines, there was no correlation between receptor numbers or affinity at $4^{\circ} \mathrm{C}$ and cellular response at $37^{\circ} \mathrm{C}$ to the addition of TNF.

\section{Acknowledgments}

This work was supported by the Swedish Cancer Society, John and Augusta Perssons Foundation, Magnus Bergvall Foundation, the Medical Faculty of Lund, and Inga-Britt and Arne Lundbergs Foundation.

\section{References}

1. Olsson, I., T. Olofsson, and N. Mauritzon. 1981. Characterization of mononuclear blood cell derived differentiation inducing factors (DIFs) for the human promyelocytic leukemic cell line HL-60. J. Natl. Cancer Inst. 67:1225-1230.

2. Olsson, I., M. G. Sarngadharan, T. R. Breitman, and R. C. Gallo. 1984. Isolation and characterization of a T-lymphocyte derived differentiation inducing factor (DIF) for myeloid leukemic cells. Blood. 63: 510-517.

3. Chiao, J. W., W. F. Freitag, J. C. Steinmetz, and M. Andreff. 1981. Changes of cellular markers during differentiation of HL-60 promyelocytes to macrophages as induced by $T$ lymphocyte conditioned medium. Leuk. Res. 5:477-489.

4. Leung, K., and J. W. Chiao. 1985. Human leukemia cell maturation induced by T-cell lymphokine isolated from medium conditioned by nórmal lymphocytes. Proc. Natl. Acad. Sci. USA. 82:1209-1213. 
5. Carswell, E. A., L. J. Old, R. L. Kassel, S. Green, N. Fiore, and B. Williamson. 1975. An endotoxin-induced serum factor that causes necrosis of tumors. Proc. Natl. Acad. Sci. USA. 25:3666-3670.

6. Matthews, N., H. C. Ryley, and M. L. Neale. 1980. Tumor necrosis factor from the rabbit. IV. Purification and chemical characterization. Br. J. Cancer. 42:416-422.

7. Williamson, B. D., E. A. Carswell, B. Y. Rubin, J. S. Prendergast, and L. J. Old. 1983. Human tumor necrosis factor produced by human B-cell lines: synergistic cytotoxic interaction with human interferon. Proc. Natl. Acad. Sci. USA. 80:5397-5401.

8. Pennica, D., G. E. Nedwin, J. S. Hayflick, P. H. Seeburg, R. Derynck, M. A. Palladino, W. J. Kohr, B. B. Aggarwal, and D. V. Goeddel. 1984. Human tumor necrosis factor: precursor structure, expression and homology to lymphotoxin. Nature (Lond.). 312:724-729.

9. Wang, A. M., A. A. Creasey, M. B. Ladner, L. S. Lin, J. Strickler, J. N. Van Arsdell, R. Yamamoto, and D. F. Mark. 1985. Molecular cloning of the complementary DNA for human tumor necrosis factor. Science (Wash. DC). 228:149-151.

10. Marmenout, A., L. Fransen, J. Taverenier, J. Van der Heyden, R. Tizard, E. Kawashima, A. Shaw, M.-J. Johnson, D. Semon, R. Muller, M.-R. Ruysschaert, A. Van Vliet, and W. Fiers. 1985. Molecular cloning and expression of human tumor necrosis factor and comparison with mouse tumor necrosis factor. Eur. J. Biochem. 152:515-522.

11. Fransen, L., R. Muller, A. Marmenout, J. Tavernier, J. Van der Heyden, E. Kawashima, R. Tizard, H. Van Heuverswyn, A. Van Vliet, M.-R. Ruysschaert, and W. Fiers. 1985. Molecular cloning of mouse tumor necrosis factor CDNA and its eukaryotic expression. Nucleic Acid Res. 13:4417-4429.

12. Shirai, T., H. Yamaguchi, H. Ito, and C. W. Todd. 1985. Cloning and expression in Escherichia coli of the gene for human tumour necrosis factor. Nature (Lond.). 313:803-806.

13. Aggarwal, B. B., W. J. Kohr, P. E. W. Hass, B. Moffat, S. A. Spencer, W. J. Henzel, T. S. Bringman, G. E. Nedwin, D. V. Goeddel, and R. N. Harkins. 1985. Human tumor necrosis factor. J. Biol. Chem. 260:2345-2354.

14. Beutler, S., D. Greenwald, J. D. Hulmes, M. Chang, Y.-C. E. Pan, J. Mathison, R. Ulevitch, and A. Cerami. 1985. Identity of tumour necrosis factor and the macrophage-secreted factor cachectin. Nature (Lond.). 316:552-554.

15. Torti, F. M., B. Dieckmann, B. Beutler, A. Cerami, and G. M. Ringold. 1985. A macrophage factor inhibits adipocyte gene expression: An in vitro model of cachexia. Nature (Lond.). 229:867-869.

16. Sugarman, B. J., B. B. Aggarwal, P. E. Hass, I. S. Figari, M. A. Palladino, and H. M. Shepard. 1985. Recombinant human tumor necrosis factor- $\alpha$ : effects on proliferation of normal and transformed cells in vitro. Science (Wash. DC). 230:943-945.

17. Baglioni, C., S. McCandless, J. Tavernier, and W. Fiers. 1985. Binding of human tumor necrosis factor to high affinity receptors on HeLa and lymphoblastoid cells sensitive to growth inhibition. J. Biol. Chem. 260:13395-13397.

18. Rubin, B. Y., S. L. Anderson, S. A. Sullivan, B. D. Williamson, E. A. Carswell, and L. J. Old. 1985 . High affinity binding of ${ }^{125} \mathrm{I}$-labeled human tumor necrosis factor (LuKII) to specific cell surface receptors. J. Exp. Med. 162:1099-1104.

19. Aggarwal, B. B., T. E. Eessalu, and P. E. Hass. 1985. Characterization of receptors for human tumour necrosis factor and their regulation by $\gamma$-interferon. Nature (Lond.). 318:665-667.

20. Collins, S. J., R. C. Gallo, and R. E. Gallagher. 1977. Continuous growth and differentiation of human myeloid leukemic cells in suspension culture. Nature (Lond.). 270:347-349.

21. Sundström, C., and K. Nilsson. 1976. Establishment and characterization of a human histiocytic lymphoma cell-line (U-937). Int. $J$. Cancer. 7:565-577.

22. Lozzio, C. B., and B. B. Lozzio. 1975. Human chronic myelogenous leukemia cell-line with positive Philadelphia chromosome. Blood. 45:321-324.

23. Koeffler, C. B., and D. W. Golde. 1978. Acute myelogenous leukemia: a human cell line responsive to colony-stimulating activity. Science (Wash. D.C.) 200:1153-1156.

24. Li, C. Y., K. W. Lam, and K. T. Yam. 1973. Esterases in human leukocytes. J. Histochem. Cytochem. 21:1-10.

25. Bennett, J. M., D. Catovsky, M.-T. Daniel, G. Flandrin, D. A. G. Galton, H. R. Gralnick, and C. Sultan. 1976. Proposals for the classification of the acute leukemias. French-American-British (FAB) cooperative group. Br. J. Haematol. 33:451-458.

26. Ogawa, M., O. C. Grush, R. F. O'Dell, H. Hara, and M. D. MacEachern. 1977. Circulating erythropoietic precursors assessed in culture: characterization in normal men and patients with hemoglobinopathies. Blood. 50:1081-1092.

27. Tejedor, S., and J. P. G. Ballasta. 1982. Iodination of biological samples without loss of functional activity. Anal. Biochem. 127:143149.

28. Calvo, J. C., J. P. Radicella, and E. H. Charreau. 1983. Measurement of specific radioactivities in labelled hormones by self-displacement analysis. Biochem. J. 212:259-264.

29. Bretz, R., and W. Stäubli. 1977. Detergent influence on rat liver galactosyltransferase activities towards different acceptors. Eur. J. Biochem. 77:181-192.

30. Hultberg, B., S. Lindsten, and S. Sjöblad. 1976. Molecular forms and activities of glycosidases in cultures of amniotic-fluid cells. Biochem. J. 155:599-605.

31. Jesaitis, A. J., J. R. Naemura, R. G. Painter, L. A. Sklar, and C. G. Cochrane. 1983. The fate of an $\mathrm{N}$-formylated chemotactic peptide in stimulated human granulocytes. Subcellular fractionation studies. $J$. Biol. Chem. 258:1968-1977.

32. Breitman, T. R., S. E. Selonick, and S. J. Collins. 1980. Induction of differentiation of the human promyelocytic leukemia cell line (HL60) by retinoic acid. Proc. Natl. Acad. Sci. USA. 77:2936-2940.

33. Olsson, I., U. Gullberg, I. Ivhed, and K. Nilsson. 1983. Induction of differentiation of the human histiocytic lymphoma cell line $U .937$ by 1 $\alpha, 25$-dihydroxycholecalciferol. Cancer Res. 43:5862-5867.

34. Tartakoff, A. M. 1983. Perturbation of vesicular traffic with the carboxylic ionophore Monensin. Cell. 32:1026-1028.

35. Rosenthal, H. 1967. A graphic method for the determination of binding parameters in a complex system. Anal. Biochem. 20:525-532.

36. Gustavsson, A., F. Mitelman, T. Olofsson, and I. Olsson. 1984. The relationship between growth agar, karyotype and prognosis in acute nonlymphocytic leukemia. Scand. J. Haematol. 32:351-363.

37. Degliantoni, G., M. Murphy, M. Kobayashi, M. K. Francis, B. Perussia, and G. Trinchieri. 1985. Natural killer (NK) cell-derived hematopoietic colony-inhibiting activity and NK cytotoxic factor. Relationship with tumor necrosis factor and synergism with immune interferon. J. Exp. Med. 162:1512-1530.

38. Broxmeyer, H. E., B. Y. Rubin, S. Cooper, L. Lu, and D. E. Williams. 1985. Suppressive influence of human tumor necrosis factor (TNF) on human bone marrow hematopoietic progenitor cells in vitro is synergistic with the suppressive effects of human $\gamma$-interferon. Blood. 66(Suppl. 1):146a. (Abstr.)

39. Celada, A., R. Allen, I. Esparza, P. W. Gray, and R. D. Schreiber. 1985. Demonstration and partial characterization of the interferongamma receptor on human mononuclear phagocytes. J. Clin. Invest. 76: 2196-2205.

40. Dunn, W. A., A. L. Hubbard, and N. N. Aronson, Jr. 1980. Low temperature selectively inhibits fusion between pinocytic vesicles and lysosomes during heterophagy of ${ }^{125} \mathrm{I}$-asialofetuin by the perfused rat liver. J. Biol. Chem. 255:5971-5978.

41. Tycko, B., C. H. Keith, and F. R. Maxfield. 1983. Rapid acidification of endocytic vesicles containing asialoglycoprotein in cells of a human hepatoma line. J. Cell. Biol. 97:1762-1776.

42. Marshall, S. 1985. Degradative processing of internalized insulin in isolated adipocytes. J. Biol. Chem. 260:13517-13523.

43. Basu, S. K., J. L. Goldstein, R. G. W. Anderson, and M. S. Brown. 1981. Monensin interrupts the recycling of low density lipoprotein receptors in human fibroblasts. Cell. 24:493-502. 